\title{
RESIDENTS' ATTITUDES TOWARDS THE IMPACT OF MATERIAL HERITAGE IN UNDEVELOPED AREAS: ZENICA-DOBOJ CANTON CASE STUDY
}

\author{
Zrinka Zadel \\ Nikolina Šerić \\ Lejla Dervišević
}

https://doi.org/10.20867/tosee.05.37

\begin{abstract}
Purpose - This paper will explore the importance of material cultural heritage as a factor of an area's tourism development. Zenica-Doboj Canton is located in the central part of Bosnia and Herzegovina. Canton's development of its tourist offer could be based on its material cultural and historical heritage and tourism in that area could take place throughout the year if other offers of services and products enabled it. This paper has a theoretical and an empirical value since both quantitative and qualitative methods will be used.

Methodology - In addition to this, desk research of the existing literature will be carried out and the secondary data will be used to analyze the current state of tourism. Furthermore, authors will conduct an empirical research using qualitative methods of analysis. The empirical research is based on a structured questionnaire. More precisely, the local population of the Zenica-Doboj Canton will be questioned by using a sampling method in order to determine their role and importance in the product of cultural tourism. Based on the conducted survey through the SWOT analysis, the advantages and disadvantages of cultural tourism will be determined.

Findings - The positive conclusion of the survey is that residents see cultural tourism as the most representative form of tourism in the Zenica-Doboj Canton whose development could significantly improve the economic situation of this particular area. A model for a product development will be presented in this paper on the basis of the obtained results. Contribution - It is concluded that the population's interest opens up the possibility of adapting the offer to tourists. Therefore, it is necessary to include the local population in the product formation because they are part of the product.

Keywords: cultural tourism; material heritage; tourist product; local residents;
\end{abstract}

\section{INTRODUCTION}

Local population is the part of cultural-tourist product. No matter who is the holder of the offer, the local population should be included in forming tourist product. They are owner of the local cultural heritage and local government must respect it. If the locals' requirements aren't respected, it is not uncommon in that case that they also ignore local government tries to develop tourist product. Locals should be respected, as well as, because of their possible family stories, ie. legends, which should be included in the tourist product. Quality of the product also depends of how much they participate in it. On the other hand, if tourism is uncontrollably developed, over carrying capacity, it could have negative impact to the locals' quality of life. All in all, if locals aren't satisfied in their area, there are no much possibilities tourist will be. 
ToSEE - Tourism in Southern and Eastern Europe, Vol. 5, pp. 787-800, 2019

Z. Zadel, N. Šerić, L. Dervišević: RESIDENTS' ATTITUDES TOWARDS THE IMPACT OF

\section{LITERATURE REVIEW}

Culture could be described as representing an entire identity of a certain nation or a certain time period. Cultural tourism is clearly about more than built heritage, immovable installations and museums, or other permanent attractions (Douglas, Ilde, 2017, 105). Cultural sights, attractions and events provide an important motivation for travel, and travel in itself generates culture. But it is only in recent decades that the link between culture and tourism has been more explicitly identified as a specific form of consumption: cultural tourism (Richards, 2018, 12). Speaking of cultural heritage, it comprises both tangible and intangible elements, such as buildings, monuments, archeological sites, traditions, beliefs, etc. Furthermore, cultural tourism, heritage tourism or cultural heritage tourism is developed as a sustainable type of tourism, orienting on cultural heritage and wanting to avoid the mass character of tourism. Cultural heritage is surely one of the main reasons and a motivation for tourists who want to explore the culture of a particular nation (Lekić, Kolesar, Zajec,2018, 57).

Furthermore, cultural heritage is an important element of the presentation of an area, the bearer of identity of a certain community and one of the most important resources of cultural tourism. It can become a generator of development with the help of a wellplanned tourism valorisation strategy (Slunjski, 2018, 11). The cultural heritage, as well as the natural one, is sensitive to inappropriate use and maintenance (Demonja, Gredičak, $2015,190)$. There are many definitions of cultural heritage, as well as of tangible and intangible elements. However, the World Tourism Organization of 1985 accepts the Declaration on the Protection of Natural, Cultural and Historical Heritage. According to this Declaration, (Gredičak 2009, 198) the cultural heritage of one nation represents works of its artists, architects, composers, writers and philosophers, as well as works of unknown authors which have become part of national wealth. According to Cifrić, heritage is an all human creation in one place which one community inherits and disposes with. It is important to mention the fact that the tangible heritage is inseparably connected to intangible heritage and great efforts are being made for their preservation. Finally, heritage can also be defined as a social good which belongs to the past, present and future (Cifrić, 2014, 11).

The definition from the Declaration is an exception that refers to intangible cultural heritage and that has been included in use afterwards. It refers to all features of intangible heritage of one nation, such as the traditional dance and folklore, knowledge and skills, rituals and beliefs and different types of events. By combining these two types of cultural heritage, the historic cities with their former lifestyles are included. In the course of the civilization development, heritage used to refer to a community or to smaller geographical units. However, the concept of heritage is nowadays applied on an international or a global level. Furthermore, the main characteristic of cultural heritage is that it only links to one specific territory and it is unique. In the center of the heritage concept is the society with its cultural attitudes, needs and reasons that show the value of cultural heritage. Moreover, heritage is not only a reflection of the past since it also includes its adaptation to present cultural, social, public and political needs (Dumbović Bilušić 2013, 8). The concept itself is a dynamic and responsible action process in society through which it manifests its needs. Theoretically speaking, there are three types of heritage: the material, social and spiritual one. More precisely: a) natural goods- nature 
ToSEE - Tourism in Southern and Eastern Europe, Vol. 5, pp. 787-800, 2019

Z. Zadel, N. Šerić, L. Dervišević: RESIDENTS' ATTITUDES TOWARDS THE IMPACT OF

and wildlife b) human activity in nature- cultural environment c) built tangible cultural goods (built heritage) and intangible goods (tradition, beliefs and skills) d) social (marriage, family, institutions, etc.) e) spiritual heritage (religion, value, moral). The notion of natural heritage implies the untouched nature and natural landscapes without the physical impact of people. With their actions and activities, people create a cultural environment with a certain amount of cultural value which remains for the future generations. The built cultural heritage represents built objects which had a cultural role at the time of their construction. The social cultural heritage represents the ways of communication and making human connections in terms of marriage, family and cultural customs. Finally, spiritual heritage connects certain religious and cultural aspects of one population, moral values and the act of separating good from bad. If the heritage is valorized in the right way, it can have a big impact on people. Since the tangible cultural heritage generates two types of values, the non-economic (cultural) and the economic (use and non-use) one, the valuation process requires a holistic approach. In order to explain the specific characteristics of the valuation process, whether it is an economic or non-economic (cultural) one, it is important to understand the differences between types of values that tangible cultural heritage demonstrates (Matečić 2016, 76). Therefore, it can be concluded that tangible cultural heritage has certain values. The first one is a value that represents a physical, visual image of heritage and it can in certain situations be experienced with all human senses. The feeling of well-being which can be produced from culture usually comes from this value of cultural heritage. The symbolic value of the tangible cultural heritage would be the fact that it describes the experience of the historical and cultural importance and it is usually used for educational purposes. The religious meaning of cultural historical sites and learning about the confirmed world religions represents a spiritual value of the material heritage and makes people feel respect for a certain religion. If we take into consideration the character of cultural heritage, it could be said that it represents the common values of a certain society, allowing an easier connection between people, ie. between tourists and local population.

Resident's attitudes toward tourism development is a subject of research for more than 30 years (Andereck, Vogt, 2000, 207). Authors Marzuki $(2012,200)$ has concluded that locals will support tourism development in their society when they are expecting benefits from tourism activities. Lepp (2007) in his results concluded that residents have consistently positive attitudes towards tourism. Positive attitudes result from residents' belief that tourism creates community development, improves agricultural markets, generates income, and finally, that tourism brings random good fortune. Authors Simao and Moso (2013) from their research concluded that there is a lack of public participation in the decision-making processes. In general, there is a support from the residents' to tourism development, but there are wearing signs that ought to be taken into consideration by planners and decision makers. Public participation in tourism development by the community can be seen in two ways: participation in decisionmaking (1) and participation in the benefits of tourism (2) (Timothy, Boyd, 2003, 181). Author De Kadt (2003) divided the contact of the tourist and the host into three categories: when tourists purchase goods from the host (1); when tourists and local residents share space, such as a beach, a train or a bus, restaurant or a bar (2); when tourists and hosts meet with the primary goal of cultural exchange (3). The first two types are most commonly connected to negative aspects, while the third one is considered as positive. 
ToSEE - Tourism in Southern and Eastern Europe, Vol. 5, pp. 787-800, 2019

Z. Zadel, N. Šerić, L. Dervišević: RESIDENTS' ATTITUDES TOWARDS THE IMPACT OF

As it has been mentioned earlier, every part of a community or a territory is the holder of a certain part of cultural heritage, so it's authentic for every region. The scientific benefit which results from cultural heritage is unmeasurable because its value is of great significance both in theory and in practice. But however, the economic influence of (cultural) tourism can also be negative for destinations as the prices increase in real-estate property, goods and services as well as many others. In a broad context, progress of tourism development contributes to both profits and costs to local economy as higher demand from tourists will significantly influence an increment in prices and fees of tourism products and services offered in tourist destination (Marzuki 2012, 200).

\section{ANALYSIS OF CULTURAL TOURISM OF THE ZENICA-DOBOJ CANTON}

Some of the most important cultural and historical monuments of Bosnia and Herzegovina, precisely 49 of them, can be found in the Zenica- Doboj Canton: the Mile - Royal Table Good, the graveyard of medieval Bosnian kings, the royal city of Bobovac, a medieval Bosnian fortress, significant religious facilities, etc. Archaeological findings are of utmost importance since they indicate the progression of life since the prehistoric times in this particular area. Numerous remains of settlements and fortresses originate from the Neolithic period and the Metal age and can be found in almost all of the Canton municipalities. This area was known as Iliyricum, a Roman historic province that continued the process of civilization at numerous archaeological sites. In the upper part of the river Bosnia, around the town of Visoko, an economic center of the medieval Bosnian state was organized. Moreover, numerous key objects from that period (Bobovac, Vrandukča Fortress, Maglajska Fortress, Tešanj Fortress) are the bearers of the identity of that area and have influenced its development. The Kingdom of Bosnia became the most powerful state in the territory of South Slavs. The preconditions for passing this remarkable Eurasian border of worlds, civilizations, religions and world views to this geographic space have shaped the historic destiny of Bosnia. The Ottoman rule remained in Bosnia for more than 400 years. During that period, the core of the cities of Bosnia and Herzegovina have been formed and as such, are still recognizable nowadays (čaršijas and mahalas). The Berlin Congress of 1878 gave the AustroHungarian permission to occupy Bosnia and Herzegovina. As a result of that decision, the Austro-Hungarian Monarchy remained in these areas for 40 years, leaving a deep mark on the way of life in Bosnia and Herzegovina and its architectural heritage (Studija kulturno-istorijskog i prirodnog naslijeđa, 2007, 13).

The cultural heritage area of the Zenica-Doboj Canton is regulated and implemented through the Law on Protection of Cultural Heritage. This law defines measures of action, protection, but also the use and maintenance of heritage goods. In addition to this, it comprises the conditions for determining the owner and the holder who will decide on the protection of cultural property and heritage. It also predicts a future establishment of cantonal level heritage protection institutes whose function would concern the management of cultural heritage. Their task would involve keeping a register of heritage goods, as well as forming a list of attractions and taking care of their preservation. Unfortunately, this Department has never been formed and isn't likely to be formed in the near future. However, a Strategy of the Cultural Policy of the Zenica-Doboj Canton 
ToSEE - Tourism in Southern and Eastern Europe, Vol. 5, pp. 787-800, 2019

Z. Zadel, N. Šerić, L. Dervišević: RESIDENTS' ATTITUDES TOWARDS THE IMPACT OF

exists and specific information on cultural heritage were requested from the cantons of the Canton area. Almost everyone pointed out the problem of the lack of a responsible institution that would protect the cultural heritage of this area.

The first table in this paper presents 13 attractions of the Zenica-Doboj Canton. They will be divided into four groups: affirmed attraction, attraction in the process of affirmation, not affirmed attraction and not attraction. The term Affirmed attraction refers to an attraction that is recognized by domestic and foreign tourists. Attraction in the process of affirmation means that an attraction is recognized only by domestic tourists. Not affirmed attraction is an attraction recognized only by local population. Not an attraction group refers to resources that are still not in the group of attractions and aren't likely to be in the near future (one year).

Table 1: The Zenica-Doboj Canton attractions analysis

\begin{tabular}{|l|c|c|c|c|}
\hline \multicolumn{1}{|c|}{$\begin{array}{c}\text { (Potential) } \\
\text { Attraction }\end{array}$} & $\begin{array}{c}\text { Affirmed } \\
\text { attraction }\end{array}$ & $\begin{array}{c}\text { Attraction in } \\
\text { the process of } \\
\text { affirmation }\end{array}$ & $\begin{array}{c}\text { Not affirmed } \\
\text { attraction }\end{array}$ & $\begin{array}{c}\text { Not an } \\
\text { attraction }\end{array}$ \\
\hline Vranduk & $\mathrm{X}$ & & & \\
\hline Kraljeva sutjeska & $\mathrm{X}$ & & & \\
\hline $\begin{array}{l}\text { The Royal Town of } \\
\text { Bobovac }\end{array}$ & $\mathrm{X}$ & & & \\
\hline Zgošča Tombstone & & $\mathrm{X}$ & & \\
\hline Synagogue & $\mathrm{X}$ & $\mathrm{X}$ & & \\
\hline $\begin{array}{l}\text { Museum of the City } \\
\text { of Zenica }\end{array}$ & $\mathrm{X}$ & & & \\
\hline Church of St. Ilija & & $\mathrm{X}$ & & \\
\hline $\begin{array}{l}\text { Residence of } \\
\text { Uzeirbeg }\end{array}$ & & $\mathrm{X}$ & & \\
\hline Mussala u Zenici & & $\mathrm{X}$ & $\mathrm{X}$ & \\
\hline Church of St. Lady & & & & \\
\hline $\begin{array}{l}\text { Tešanj } \\
\text { Fortress Gradina }\end{array}$ & $\mathrm{X}$ & & & \\
\hline White Mosque & & & & \\
\hline $\begin{array}{l}\text { Mosque of Sultan } \\
\text { Ahmed }\end{array}$ & & & & \\
\hline
\end{tabular}

Source: Authors

The most important information carried out from the first table would be the fact that there are seven (Vranduk, Kraljeva sutjeska, The Royal Town of Bobovac, Synagogue, Museum of the city of Zenica, Church of St. Lady and Tešanj Fortress Gradina) out of 13 attractions that are already affirmed. Another positive fact is that there are four attractions (Zgošća Tombstone, Church of St. Ilija, Residence of Uzeirbeg and Mussala in Zenica) in the process of affirmation. In addition to this, there are two attractions waiting to be part of the second group (White Mosque, Mosque of Sultan Ahmed) None of the (potential) attractions on the list belong to the fourth group listed as not attraction.

The empirical research of this paper consists of an analysis of results of local population surveys. One of the questions was to evaluate the importance of 13 attractions from the previous table. The results are shown below. 
ToSEE - Tourism in Southern and Eastern Europe, Vol. 5, pp. 787-800, 2019

Z. Zadel, N. Šerić, L. Dervišević: RESIDENTS' ATTITUDES TOWARDS THE IMPACT OF

\section{EMPIRICAL RESEARCH OF THE POSSIBILITY AND POTENTIAL OF DEVELOPMENT OF CULTURAL TOURISM IN ZENICA-DOBOJ CANTON}

The main aim of this empirical research is to find out how are the locals of the ZenicaDoboj Canton informed about local cultural heritage. This aim comes from the fact that the quality of the tourist-cultural product depends on how much local population is informed about local area heritage. In the survey locals had to answer, as well as, questions about their participation in the tourism development and the main part are their ratings to the cultural sights of the Zenica-Doboj Canton.

The research was conducted by a survey method. The survey was completed by 132 respondents and the sample included the local residents of the Zenica-Doboj Canton. The questionnaire was organized in three parts. In the first part, 14 statements on cultural tourism and cultural potentials of the Canton were presented and the respondents had to answer whether they agreed with this or not. In the second part, 14 potential tourist attractions were mentioned and the respondents had the opportunity to evaluate them according to their importance. The last part of the survey concerned the demographic components of the respondents. $68 \%$ of the respondents were women and $32 \%$ were men. The age of respondents was ranked in six groups. The majority of respondents (38\%) belonged to a group whose respondents were between 16 and 25 years old. 57\% respondents (74 of them) were highly educated and only 4 respondents had a master or a $\mathrm{PhD}$ degree.

Concerning the first statement in the survey, 94\% of respondents answered that they believe tourism is important for the development of the Zenica-Doboj Canton. The next question referred to the form of tourism that should be developed in the Canton - cultural tourism, congress tourism, rural tourism or hunting and fishing tourism. 84 respondents (64\%) believe that cultural tourism should be developed in that area. Also, 84,8\% (102) of respondents answered that tourism development of the Zenica-Doboj Canton should be based on cultural tourism. Table number 2 shows answers for the following question: 'According to you, which form of cultural tourism should develop in the Zenica-Doboj Canton.?'

Table 2: Answers for the question 'According to you, which form of cultural tourism should develop in the Zenica-Doboj Canton?'

\begin{tabular}{|l|c|}
\hline The form of cultural tourism & The number of respondents \\
\hline Religious tourism & 0 \\
\hline Heritage tourism & 14 \\
\hline Historical tourism & 42 \\
\hline Industrial tourism & 30 \\
\hline Event tourism & 46 \\
\hline Total & 132 \\
\hline
\end{tabular}

Source: Authors 
ToSEE - Tourism in Southern and Eastern Europe, Vol. 5, pp. 787-800, 2019

Z. Zadel, N. Šerić, L. Dervišević: RESIDENTS' ATTITUDES TOWARDS THE IMPACT OF

As it can be concluded from the table, $34,8 \%$ of respondents answered that event tourism should be developed in the Zenica-Doboj Canton. Furthermore, $31.8 \%$ of respondents believe the Historical tourism should develop in this area. Industrial tourism was the answer for $22,8 \%$ of respondents. Only $10,6 \%$ of respondents think heritage tourism would be ideal for this area. Finally, nobody answered that religious tourism should be developed in the Zenica-Doboj Canton.

Table 3 presents answers for three questions/statements from the survey: Do you participate in the decision-making process related to tourism?; Do you know most of cultural attractions of Zenica-Doboj Canton?; Zenica-Doboj Canton is recognizable by its cultural sights; Should cultural resources be converted into a tourism product?;

Table 3: Residents' inclusion/knowledge about Zenica-Doboj Canton tourism development

\begin{tabular}{|l|c|c|}
\hline \multirow{2}{*}{ Questions } & \multicolumn{2}{|c|}{ Answers } \\
\cline { 2 - 3 } & 16 & Yes \\
\hline $\begin{array}{l}\text { Do you participate in the decision-making } \\
\text { process related to tourism? }\end{array}$ & 74 & 58 \\
\hline $\begin{array}{l}\text { Do you know most of the cultural attractions } \\
\text { of Zenica-Doboj Canton? }\end{array}$ & 76 & 56 \\
\hline $\begin{array}{l}\text { Zenica-Doboj Canton is recognizable by its } \\
\text { cultural sights. }\end{array}$ & 126 & 6 \\
\hline $\begin{array}{l}\text { Should cultural resources be converted into a } \\
\text { tourism product? }\end{array}$ & & 5 \\
\hline
\end{tabular}

Source: Authors

Despite the fact that only $12,1 \%$ respondents participate in the decision-making process related to tourism, $56,1 \%$ of them know about the cultural attractions in their living area and $58 \%$ believe that the Zenica-Doboj Canton is recognizable by its cultural sights. Moreover, almost everyone $(95,5 \%)$ answered that cultural resources should be converted into a tourism product.

The first graph of this paper shows respondents' answers for the following four statements: (1) Development of cultural tourism encourages the development of the entire economy within the bounds of Canton.; (2) Diverse tourist and cultural offer provide a better way of life for the local population.; (3) It is necessary to involve all stakeholders (local residents, holders of offers, cultural institutions, cantonal administration) in decision-making related to cultural tourism.; (4) It is necessary to present the activities of cultural institutions to the public in and outside of Bosnia and Herzegovina. It was expected that the respondents were more likely to give a positive answer to all of these statements. 
ToSEE - Tourism in Southern and Eastern Europe, Vol. 5, pp. 787-800, 2019

Z. Zadel, N. Šerić, L. Dervišević: RESIDENTS' ATTITUDES TOWARDS THE IMPACT OF ...

\section{Graph 1: Answers for five statements from the survey}

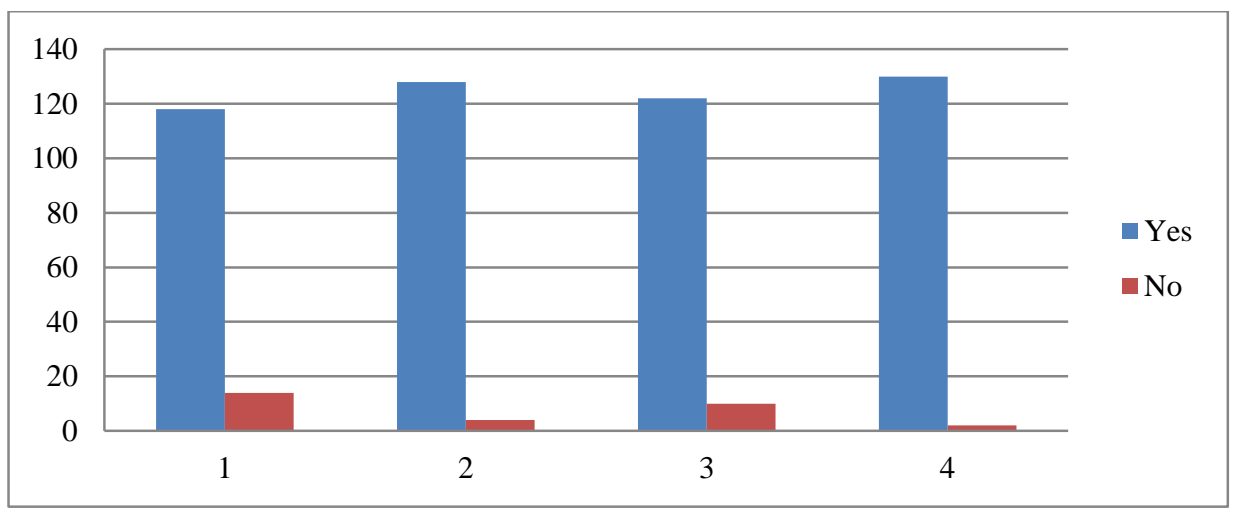

Source: Authors

$89,4 \%$ of respondents agree with the statement that development of cultural tourism encourages the development of the entire economy within the bounds of Canton. $97 \%$ of respondents agree with the statement that cultural tourism should initially attract mostly domestic tourists. 92,4\% of respondents believe diverse tourist and cultural offer provide a better way of life of the local population. Finally, 98,5\% of respondents claim that it is necessary to present the activities of cultural institutions to the public in and outside of Bosnia and Herzegovina. Having presented all the answers, it can be concluded that the local population is conscious of the importance of cultural tourism development. It is one of the first steps because the local population is the main stakeholder in tourism development in general.

The last question before rating the importance of cultural heritage was Who do you think is responsible for the development of cultural tourism?. The following graph presents the answers.

Graph 2: Answers for the question Who do you think is responsible for the development of cultural tourism?

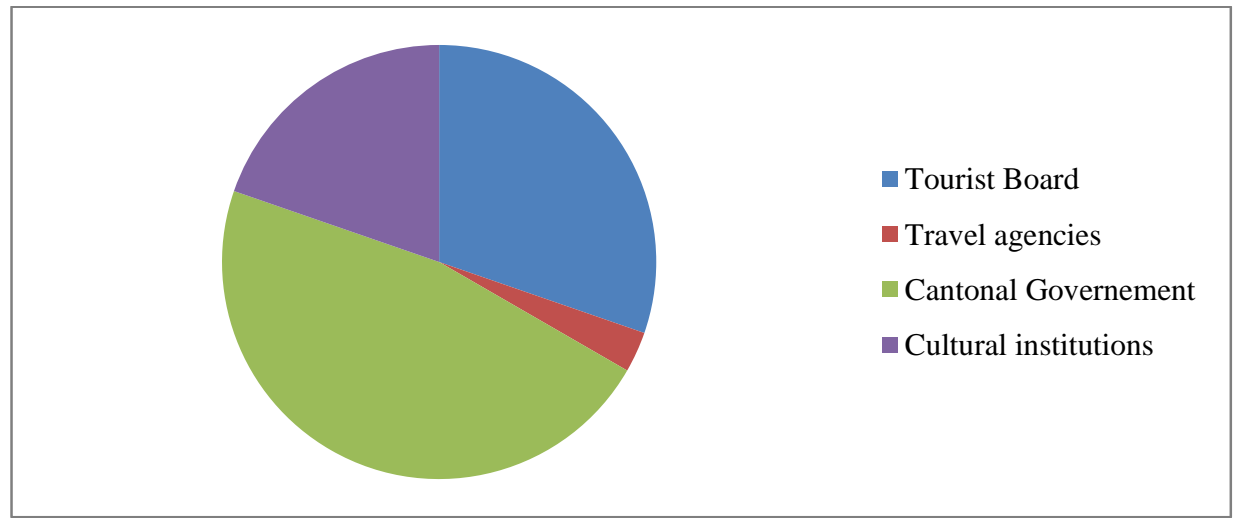

Source: Authors 
ToSEE - Tourism in Southern and Eastern Europe, Vol. 5, pp. 787-800, 2019

Z. Zadel, N. Šerić, L. Dervišević: RESIDENTS' ATTITUDES TOWARDS THE IMPACT OF

Despite the fact that tourism isn't developed in their area to a great extent, the local population has an opinion on the matter of responsibility for the cultural tourism development in the Zenica-Doboj Canton. $47 \%$ of respondents consider the Cantonal Government responsible for the development of cultural tourism, 30,3\% of them believe it is the Tourist Board, and for 19,7\% respondents Cultural institutions assume the most important role. Finally, for only $3 \%$ of them travel agencies share that responsibility.

In the final table of the survey respondents rated the importance of the attractions of the Zenica-Doboj Canton (from the first table of paper). Respondents had the opportunity to evaluate the attractions with numbers from 1 to 5 , and they indicated the following: 1 completely unimportant, 2 - unimportant, 3 - neither important nor important, 4 - very important, 5 - most important.

Table 4: Ratings of the Zenica-Doboj Canton cultural sights

\begin{tabular}{|c|c|c|c|c|c|c|}
\hline $\begin{array}{l}\text { Cultural } \\
\text { sight }\end{array}$ & $\begin{array}{c}1 \text { - } \\
\text { completely } \\
\text { unimportant }\end{array}$ & $\begin{array}{c}2 \text { - } \\
\text { unimportant }\end{array}$ & $\begin{array}{l}3 \text { - neither } \\
\text { important } \\
\text { nor } \\
\text { important }\end{array}$ & $\begin{array}{l}4 \text { - very } \\
\text { important }\end{array}$ & $\begin{array}{c}5-\text { most } \\
\text { important }\end{array}$ & Total \\
\hline \multicolumn{7}{|c|}{ Affirmed attractions } \\
\hline $\begin{array}{l}\text { Kraljeva } \\
\text { Sutjeska }\end{array}$ & $3 \%$ & $1,5 \%$ & $9,1 \%$ & $24,2 \%$ & $62,1 \%$ & $100 \%$ \\
\hline $\begin{array}{l}\text { The Royal } \\
\text { Town of } \\
\text { Bobovac }\end{array}$ & $3 \%$ & $1,5 \%$ & $4 \%$ & $24,3 \%$ & $66,7 \%$ & $100 \%$ \\
\hline $\begin{array}{c}\text { Tešanj } \\
\text { Fortress } \\
\text { Gradina }\end{array}$ & $3 \%$ & $3 \%$ & $16,7 \%$ & $27,3 \%$ & $50 \%$ & $100 \%$ \\
\hline Vranduk & $3 \%$ & $3 \%$ & $6,3 \%$ & $33,3 \%$ & $54,4 \%$ & $100 \%$ \\
\hline Synagogue & $3 \%$ & $4,5 \%$ & $18,2 \%$ & $37,9 \%$ & $36,4 \%$ & $100 \%$ \\
\hline $\begin{array}{c}\text { Museum of } \\
\text { the city of } \\
\text { Zenica }\end{array}$ & $4,5 \%$ & $1,5 \%$ & $16,7 \%$ & $39,4 \%$ & $37,9 \%$ & $100 \%$ \\
\hline $\begin{array}{l}\text { Church of } \\
\text { St. Lady }\end{array}$ & $6,1 \%$ & $9,1 \%$ & $16,7 \%$ & $43,9 \%$ & $24,2 \%$ & $100 \%$ \\
\hline \multicolumn{7}{|c|}{ Attraction in the process of affirmation } \\
\hline $\begin{array}{c}\text { Zgošća } \\
\text { Tombstone }\end{array}$ & $3 \%$ & $6,1 \%$ & $13,6 \%$ & $37,9 \%$ & $39,4 \%$ & $100 \%$ \\
\hline $\begin{array}{l}\text { Residence } \\
\text { of Uzeirbeg }\end{array}$ & $4,5 \%$ & $6,2 \%$ & $31,8 \%$ & $33,3 \%$ & $24,2 \%$ & $100 \%$ \\
\hline $\begin{array}{c}\text { Mussala in } \\
\text { Zenica }\end{array}$ & $4,5 \%$ & $9,1 \%$ & $27,3 \%$ & $33,3 \%$ & $25,8 \%$ & $100 \%$ \\
\hline $\begin{array}{c}\text { Church of } \\
\text { St. Ilija }\end{array}$ & $6,1 \%$ & $9 \%$ & $22,8 \%$ & $37,9 \%$ & $24,2 \%$ & $100 \%$ \\
\hline \multicolumn{7}{|c|}{ Not affirmed attraction } \\
\hline $\begin{array}{c}\text { White } \\
\text { Mosque }\end{array}$ & $4,5 \%$ & $6,1 \%$ & $19,7 \%$ & $36,4 \%$ & $33,3 \%$ & $100 \%$ \\
\hline $\begin{array}{c}\text { Mosque of } \\
\text { Sultan } \\
\text { Ahmed }\end{array}$ & $1,5 \%$ & $9 \%$ & $15,2 \%$ & $36,4 \%$ & $37,9 \%$ & $100 \%$ \\
\hline
\end{tabular}

Source: Authors' processing 
ToSEE - Tourism in Southern and Eastern Europe, Vol. 5, pp. 787-800, 2019

Z. Zadel, N. Šerić, L. Dervišević: RESIDENTS' ATTITUDES TOWARDS THE IMPACT OF

Rows named not affirmed attraction, affirmed attractions and attraction in the process of affirmation were subsequently added to make it easier for the reader to understand the results. Kraljeva sutjeska, The Royal Town of Bobovac, Tešanj Fortress Gradina and Vranduk are affirmed attractions that respondents rated as the most important cultural sights in the Zenica-Doboj Canton. Synagogue, Museum of the City of Zenica and Church of St. Lady are also affirmed attractions, but respondents rated them as very important, rather than the most important. Zgošća Tombstone is an attraction in the process of affirmation and most respondents believe it to be the most important attraction. Residence of Uzeirbeg, Mussala in Zenica and Church of St. Ilija belong to the same group of attractions, but respondents rated them as very important, rather than the most important. There are two cultural sights in the group not affirmed attraction and one of them (White Mosque) is rated as very important and the other one (Mosque of Sultan Ahmed) as the most important.

Although cultural tourism as a form of tourism is not represented largely in the ZenicaDoboj Canton, respondents from that area have formed certain opinions about it. One of the main conclusions may be the desire and interest for information and education in tourism. Respondents in the survey answered that local government is the most responsible for tourism development. This is partially true, but the local population is definitely one of the main stakeholders for tourism development and for the local government their requirements and possibilities should be more important than those of the tourists.

Over the past 15 years, numerous international and local organizations and agencies, as well as dedicated projects, have dealt with various problems related to tourism in Bosnia and Herzegovina, often emphasizing the existence of great opportunities for further development.

\section{SWOT ANALYSIS}

The following table presents strengths, weaknesses, opportunities and threats (SWOT) of the cultural tourism of the Zenica-Doboj Canton.

\section{Table 5: SWOT analysis of the cultural tourism of the Zenica-Doboj Canton}

\begin{tabular}{|c|c|}
\hline STRENGTHS & WEAKNESSES \\
\hline $\begin{array}{ll}\text { - } & \text { Untouched nature, diverse cultural } \\
\text { - } & \text { Attractions with high quality potential } \\
- & \text { Different climate } \\
- & \text { Competitive prices } \\
- & \text { Good connection with other cantons } \\
- & \text { People and hospitality }\end{array}$ & $\begin{array}{ll}- & \text { Poor statistics of tourist movements } \\
- & \text { Poor infrastructure quality as well as } \\
\text { - } & \text { lack of accommodation capacity } \\
& \text { Impossible or difficult access to many } \\
\text { attractions } & \text { Administrative barriers } \\
- & \text { A complex state and cantonal } \\
\text { organization } & \text { Bad skills and knowledge about } \\
\text { tourism in general and cultural tourism } \\
\text { management }\end{array}$ \\
\hline
\end{tabular}


ToSEE - Tourism in Southern and Eastern Europe, Vol. 5, pp. 787-800, 2019

Z. Zadel, N. Šerić, L. Dervišević: RESIDENTS' ATTITUDES TOWARDS THE IMPACT OF ...

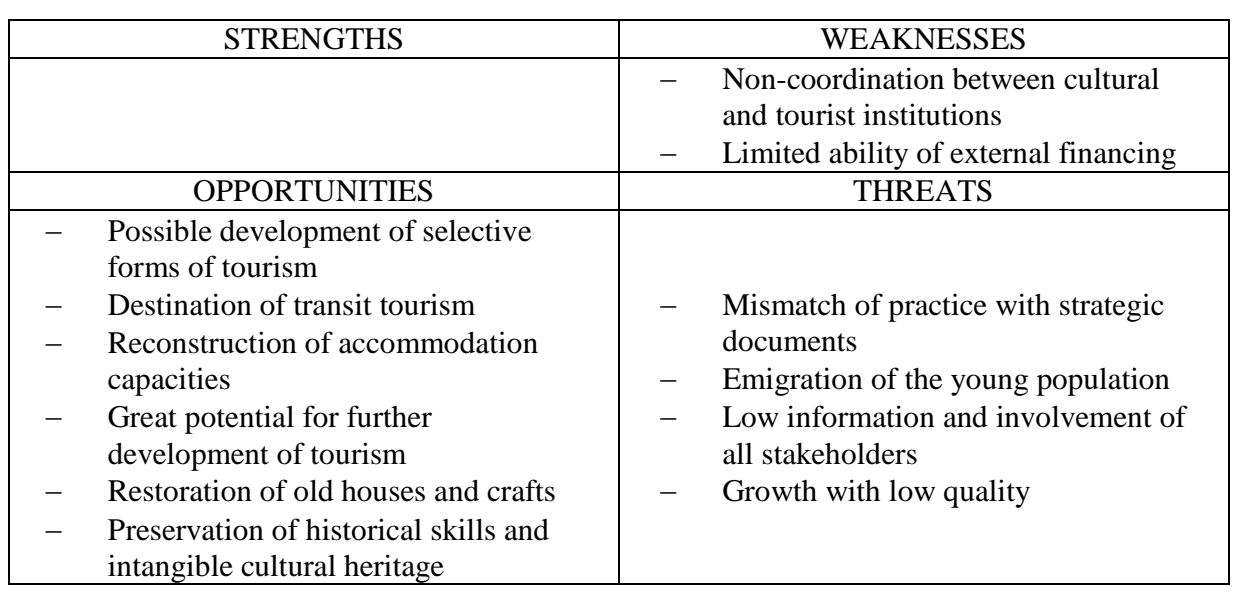

Source: Authors

In the geographic area of the Zenica-Doboj Canton, remains of the cultural and historic heritage of the Bosnian kingdom, the Roman Empire, the Ottoman Empire, the AustroHungarian empire, as well as the remains from the former Yugoslavia were found. There is, however, the possibility of exploiting the unique cultural and historical heritage in a better way. The climate is particularly suitable for visits at any season throughout the year. People and hospitality are also one of the most important factors because the local population is certainly involved in cultural tourism. However, it is necessary to build a continuous education of hospitality as a competitive advantage. Competitive and reasonable prices are extremely important due to the crisis. The prices of food, beverages and accommodation in Bosnia and Herzegovina are considerably lower than in other countries in the region. In the future, it is necessary to keep the existing prices but with a more diverse offer. Traffic connections of Canton with others are extremely good and this presents one of the main strengths of development of the Zenica-Doboj Canton.

The first of the weaknesses is certainly the lack of a unique methodology for monitoring tourist activities in the Zenica-Doboj Canton. Tourism is still largely present in the gray economy, which is difficult to register or act on. However, there are many sources of data of tourists' activities within the Canton. Some of them are inconsistent data (field data are significantly different from public statistics) and a large percentage of nonregistered tourist activities are also presented. Without quality statistics data it is difficult to prove the economic significance and the effects of tourist activity. A unique methodology at the Cantonal level and statistics are also essential for further development of tourism, including product development, innovation, promotional and other marketing activities. Undeveloped physical infrastructure is one of the main threats of cultural tourism development. The lack and neglect of road and rail infrastructures are one of the main problems in this segment. Poor quality transport infrastructure discourages potential tourists and investors, making access to the Canton difficult and disabling connectivity. A similar situation can be found with tourist accommodation infrastructure. Low quality hotels and low levels of categorization are not attractive to tourists in better financial situation. In many cases, complex state administration system blocks foreign investments and attempts to invest in tourism. Human capital is very important for tourism development. Another significant problem is the emigration of 
ToSEE - Tourism in Southern and Eastern Europe, Vol. 5, pp. 787-800, 2019

Z. Zadel, N. Šerić, L. Dervišević: RESIDENTS' ATTITUDES TOWARDS THE IMPACT OF

young and capable people due to the economic situation in the country. Also, Bosnia and Herzegovina is not a state with tourist history and there is no specific orientation in the education system regarding tourism development and tourism management. This is also maintained at the level of knowledge of cultural tourism, and people who manage the development of cultural tourism at Cantonal level are from the cultural sector, not from tourism. The relationship between these two types of stakeholders is extremely poor, as well as communication itself because they probably did not realize the importance and advantages of joint cooperation and action. This is also evidenced by the lack of appropriate documentation and drafting of strategies and plans. As a result, the possibility of exploiting any type of co-financing or foreign aid are automatically blocked.

The Zenica-Doboj Canton has a unique natural heritage that is extremely suitable for the development of selective forms of tourism, such as agrotourism, mountain, rural, adventure tourism. Its geographical position makes it one of the transit destinations because a large number of passengers pass through the Zenica-Doboj Canton during their trip and stay for a few days. Most of the hotels in the canton are private, and investors invest considerable financial resources because most hotel and other accommodation facilities are from the nineties of the last century. Considering the rich history of this area, a major step would be to rebuild old houses in towns and villages that could be converted into craft workshops, souvenir shops to help present tourists the way of life of previous generations in this area. However, due to the inconvenience, more attention needs to be paid to restoration, conservation and other processes that would preserve the remains of historic cultural heritage that becomes more sensitive over time.

Activities in the tourist market and those prescribed by law and documents are too different, and that is mentioned as one of the threats to the cultural tourism of the Canton. There is also a lack of communication between stakeholders in cultural tourism, so it is a common case of disagreement or duplication of work by cultural institutions and tourist organizations. Local population, as it is presented in the research, doesn't know much about cultural tourism but want to be informed and want to participate in its development.

\section{CONCLUSION}

Cultural tourism in the Zenica-Doboj Canton has a bright future to develop as one of the leading forms of tourism in this area. With a rich natural base, the Canton has no visually appealing built structures from the historical periods, but even a small amount of historical heritage of that area, with proper care and orientation, can be utilized for tourist purposes. Furthermore, the structure of accommodation capacities and the level of their quality are at the middle level, but there are already positive steps in that direction by building new capacities.

The results of an empirical research have shown that cultural tourism is not largely represented in the overall tourism development in this area. The surprising conclusion is that respondents are largely interested in tourist and cultural information and activities, but don't even know where to get them. They didn't show even enviable general knowledge about tourism management of the Zenica-Doboj Canton. The reason for this 
ToSEE - Tourism in Southern and Eastern Europe, Vol. 5, pp. 787-800, 2019

Z. Zadel, N. Šerić, L. Dervišević: RESIDENTS' ATTITUDES TOWARDS THE IMPACT OF

is that tourism is not a primary activity nor in the Canton itself, nor in the rest of Bosnia and Herzegovina. However, most of them are familiar with the cultural potential and are aware of its value. That fact is a confirmation that this empirical research is a good base to the future researches of the Zenica-Doboj Canton (cultural) tourism development. It is important to pay attention in the future also what locals think about tourism development, because they could rate it not only as positive. If they are not included in the forming of tourism product or in decision-making, they could rate it as negative. If local population isn't satisfied in their local area, it is not possible for tourist to be satisfied.

\section{REFERENCES}

Andereck, K. L., Vogt, C.A. (2000), "The Relationship between Residents 'Attitudes toward Tourism and Tourism Development Options", Journal of Travel Research, Vol. 39, Inc., pp. 27-36. DOI: $10.1177 / 004728750003900104$

Cifrić, I. (2014), “Očuvanje baštine u kontekstu Europske unije”, Adrias, Vol. 20, pp. 91.

Demonja, D., Gredičak, T. (2015), "Tourism and the culture in the function of local economic development", Vol. 14, No. 27, pp. 190-204.

De Kadt, E. (1979), "Social planning for tourism in the developing countries", Annals of Tourism Research, Vol. 6, No. 1, pp. 36-45, https://doi.org/10.1016/0160-7383(79)90093-8

Douglas, S., Rizzo, I. (2017), "Economics of cultural tourism: issues and perspetcives", Journal of Cultural Economics, Vol. 41, No. 2, pp. 95-107, https://doi.org/ 10.1007/s10824-017-9300-6

Dumbović Bilušić, B. (2013), "Kulturna baština u Hrvatskoj pred novim izazovima”, Kvartal, Vol. 1, No. 2 , pp. 6-1.

Gredičak, T. (2009), "Kulturna baština i gospodarski razvitak Republike Hrvatske", Ekonomski pregled, Vol. 60, No. 3-4, pp. 196-218.

Lekić R., Kolesar K., Zajec D. (2018), “Thematic route from Perun to Sv. Juraj- Cultural Tourism of Zagreb Country", International journal of multidisciplinarity in business and science, Vol. 4, No. 6, pp. 57-64.

Lepp, A. (2007), "Residents' Attitudes Towards Tourism in Bigodi Village, Uganda", Tourism Management, Vol. 28, pp. 876-885. DOI: 10.1016/j.tourman.2006.03.004

Marzuki, A. (2012), "Local residents' perceptions towards economic impact of tourism development in Phuket", Tourism, Vol. 60, No. 2, Zagreb, pp. 199-212.

Matečić, I. (2016), "Specifičnosti procesa vrednovanja materijalne kulturne baštine u turizmu", Acta Turistica', Vol. 28, No. 1, pp. 73-100.

Richards, G. (2018), “Cultural Tourism: A review of recent research and trends", Journal of Hospitality and Tourism Management, Vol. 36, pp. 12-21. DOI: 10.1016/j.jhtm.2018.03.005

Simão, J., Môsso, A. (2013), "Residents' Perceptions Towards Tourism Development: The Case of Sal Islands", International Journal of Development Issues, Vol. 12, No. 3, pp. 140-157. DOI: 10.1108/IJDI-12-2012-0076

Slunjski, R., (2018), “Turistička valorizacija nepokretne materijalne baštine”, Hrvatski geografski glasnik', Vol. 80, No. 2, pp. 111-137. DOI: 10.1016/j.jhtm.2018.03.005

Timothy, D.J., Boyd, S.W. (2003.), Heritage tourism, Pearson Education Limited, England.

"Studija kulturno-istorijskog i prirodnog naslijeđa", Dvokut Pro, Sarajevo, 2007. 
ToSEE - Tourism in Southern and Eastern Europe, Vol. 5, pp. 787-800, 2019

Z. Zadel, N. Šerić, L. Dervišević: RESIDENTS' ATTITUDES TOWARDS THE IMPACT OF ..

Zrinka Zadel, $\mathrm{PhD}$, Associate Professor

University of Rijeka

Faculty of Tourism and Hospitality Management

Tourism Department

Ika, Primorska 42, p.p. 97, 51410 Opatija, Croatia

Phone: 0038551294183

E-mail: zrinkas@fthm.hr

Nikolina Šerić, mag.oec., Assistant

University of Rijeka

Faculty of Tourism and Hospitality Management

Tourism Department

Ika, Primorska 42, p.p. 97, 51410 Opatija, Croatia

Phone: 0038551294183

E-mail: nseric@fthm.hr

Lejla Dervišević, mag.oec., Hotel Manager

Hotel Dubrovnik

Školska 10, 72000 Zenica, Bosnia and Herzegovina

Phone: 0038732202711

E-mail: info@hoteldubrovnik.ba 